Esta publicación cientifica en formato digital es continuidad de la revista impresa ISSN-Versión Impresa 0798-1406 / ISSN-Versión on line 2542-3185Depósito legal pp
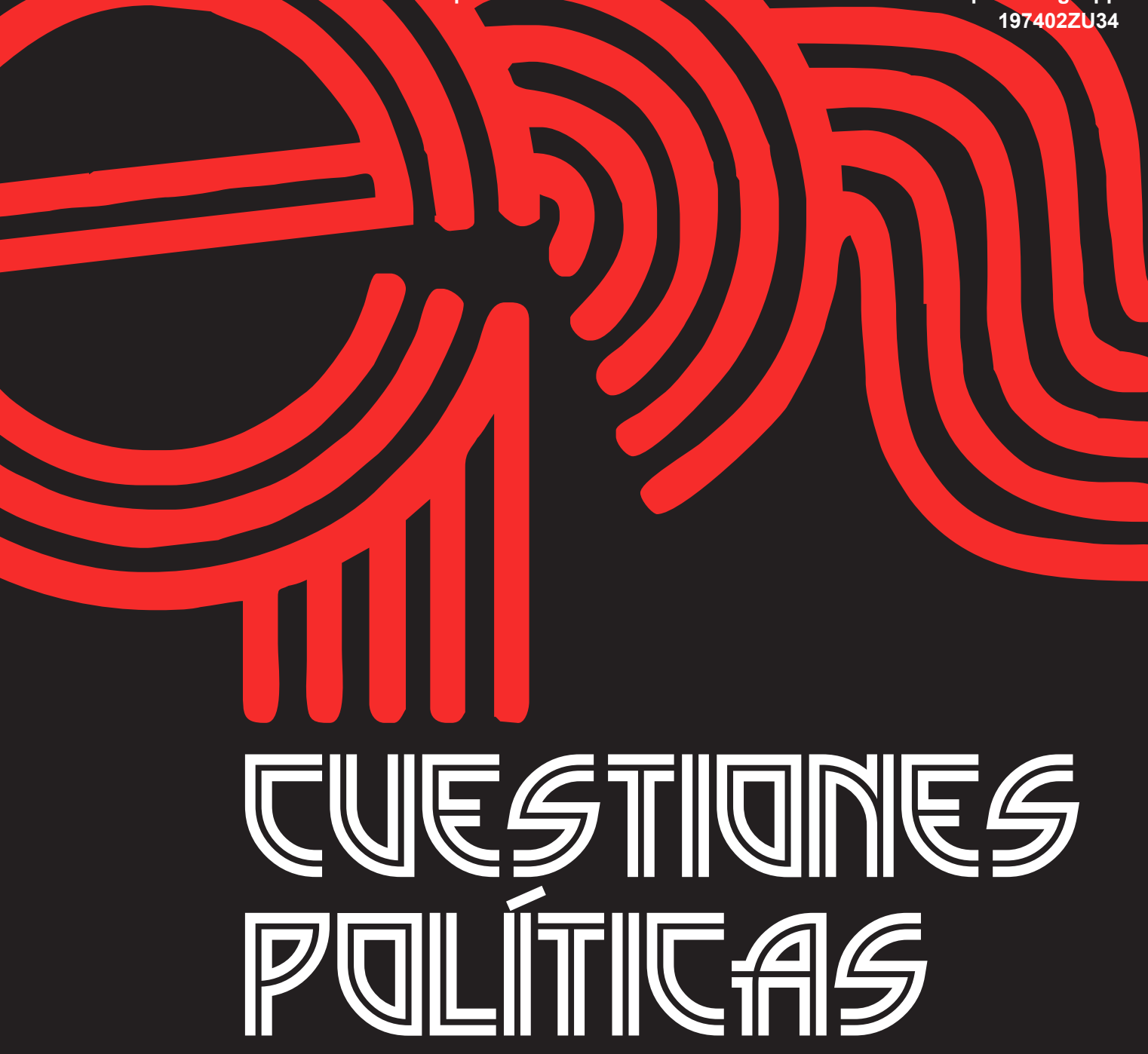

Instituto de Estudios Políticos y Derecho Público "Dr. Humberto J. La Roche" de la Facultad de Ciencias Jurídicas y Políticas de la Universidad del Zulia Maracaibo, Venezuela
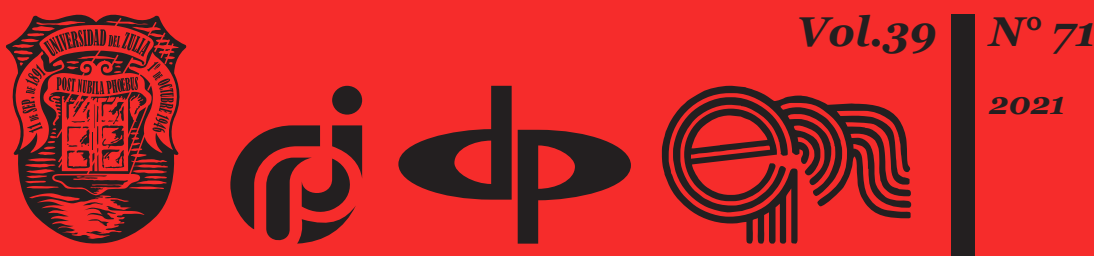


\title{
International Aspects of the Protection of Victims' Rights in the Conditions of Armed Conflict in Ukraine
}

DOI: https://doi.org/10.46398/cuestpol.3971.24

Olha Sosnina *

Oleksandr Mykytiv **

Halyna Mykytiv ***

Tetiana Kolenichenko ****

Andrii Holovach ******

\begin{abstract}
Using a comparative methodology based on documentary, the objective of the research was to analyze the international aspects involved in the defense of the rights of the victims of the armed conflict in eastern Ukraine. The priority of using military force to resolve questionable issues, national contradictions of an ethical, religious, political, territorial, economic, etc. nature that are in dispute, remains one of the essential characteristics of today's realities. Everything allows us to conclude that in almost all regions where there are armed conflicts, laws are violated and prohibited means and methods of warfare are used, related to the violation of the principles of distinction, of proportionality admitted in the process of artillery rocket attacks and air attacks of rockets and bombs, recruitment, training, financing and/or use of mercenaries in military activities, destruction of human settlements, executions in the form of intentional killings for reasons of hatred or political, ideological, racial, national, religious enmity, torture, among other inhumane behaviors and appalling atrocities, which by their nature and degree of brutality cannot go unpunished and constitute war crimes
\end{abstract} and crimes against humanity.

* Docent of department of Criminal Law and Procedure, faculty of Law, Lviv University of Trade and Economics, candidate of Law. ORCID ID: https://orcid.org/oooo-0002-0033-4487

** Teacher of the Separate Structural Subdivision «Vocational College of Economics and Law of Zaporizhzhia National University». ORCID ID: https://orcid.org/oooo-00o3-2062-7292

*** Senior teacher of department of Publishing and Editing of Zaporizhia National University, Faculty of Journalism. ORCID ID: https://orcid.org/oooo-0001-6195-2994

**** Head of the department of Social Work of the Chernihiv Polytechnic National University, Educational and Scientific Institute of Law and Social Technologies, faculty of Social Technology, Health and Rehabilitation. ORCID ID: https://orcid.org/o0oo-0003-0357-7457

***** Docent of department of Theory and History of State and Law of the State Higher Educational Institution "Uzhhorod National University", candidate of historical sciences. ORCID ID: https://orcid. org/oooo-0oo2-8314-6536 
Keywords: victims of armed conflict; human rights violations; victims' rights; armed conflict in eastern Ukraine; geopolitics in Eastern Europe.

\section{Aspectos internacionales de la defensa de los derechos de las víctimas en condiciones del conflicto armado en el este de Ucrania}

\section{Resumen}

Mediante una metodología comparativa de base documental, el objetivo de la investigación fue analizar los aspectos internacionales que implica la defensa de los derechos de las víctimas del conflicto armado en el este de Ucrania. La prioridad de uso dela fuerza militar para solucionar las cuestiones discutibles, las contradicciones nacionales de tipo ética, religiosas, políticas, territoriales, económicas, etc. que se hallan en litigio, sigue siendo una de las esenciales características de las realidades actuales. Todo permite concluir que en casi todas las regiones donde hay conflictos armados se violan las leyes y se utilizan medios y métodos de guerra prohibidos, relacionados con la violación de los principios de distinción, de proporcionalidad admitida en el proceso de los ataques de cohetes de artillería y ataques aéreos de cohetes y bombas, reclutamiento, entrenamiento, financiación y/o utilización de mercenarios en las actividades militares, destrucción de asentamientos humanos, ejecuciones en forma de asesinatos intencionados por motivos de odio o enemistad política, ideológica, racial, nacional, religiosa, torturas, entre otros comportamientos inhumana y atrocidades espantosas, que por su naturaleza y grado de brutalidad no pueden quedar impunes y se constituyen en crímenes de guerra y crímenes de lesa humanidad.

Palabras clave: víctimas de conflictos armados; violaciones a los derechos humanos; derechos de las víctimas; conflicto armado en el este de Ucrania; geopolítica en Europa del este.

\section{Introduction}

Armed aggression of the Russian Federation against Ukraine, which began in February 2014 with the annexation of the Autonomous Republic of Crimea and continued in April 2014 with the organization and support of illegal armed groups, who proclaimed the so-called "people's republics" in Donetsk and Luhansk regions, among many other problems, posed difficult tasks and questions to the Ukrainian legal system. 
The key role in responding to them, no doubt, belongs to lawyers, investigators, judges. Namely, the by the Ukrainian state's fulfillment of its obligations to both its citizens and the international community, depends on their readiness to properly understand the applicability of the provisions of international humanitarian law to the armed conflict in Ukraine, the adaptation of the relevant provisions of national law to the rules of international law, their interpretation and direct application.

Like any armed conflict, the armed conflict in the East of Ukraine is characterized by violations of the rights of civilians, in particular the right to life, health, personal liberty and security of person. Citizens experience incredible mental anguish from the experience, torture, loss of loved ones, and loss of property that was destroyed, damaged, or left in nongovernment-controlled territory.

Human rights violations in the conditions of armed conflict violate the basic international principles of human rights and humanitarian law that are enshrined in international legal documents (Grushko, 2010). Despite the international community's ratification of various conventions on international humanitarian law and the fight against their violations, as well as their partial implementation and the enshrined at the national level criminal liability for war crimes, almost all wars and armed conflicts are accompanied by commitment of serious war crimes. However, it is necessary to admit that a significant portion of such crimes remain unpunished, and those responsible are not held to criminal responsibility, taking advantage of the state's sovereignty. At the same time, the legal prospects for punishing criminals are not entirely clear and expectations for the restoration of violated rights of victims of the armed conflict in eastern Ukraine, compensation for damages, etc. remain uncertain in this situation (Grygoryan, 2009).

Of course, the responsibility of any state for the fate of its own citizens and the protection of their rights is extremely high. The issue of protection of civilians, who have been subjected to torture, inhuman and degrading, the treatment or punishment under the armed aggression of another state, as well as the protection of family members in the event of the death or unknown disappearance of their loved ones and relatives is the issue, which lies in the plane of legislative and organizational-legal initiatives of Ukraine, and must correspond to the valid mechanisms of effective investigation of violations of the Criminal Code of Ukraine and international humanitarian law that are developed by world practice. 


\section{Analysis of the recent research}

In modern Ukrainian realities, the problems of protecting victims from various crimes are more relevant than ever. Certain theoretical and practical aspects of the protection of victims' rights in the conditions of armed conflict have been the subject of research of such scholars as R.A. Avramenko, M.M. Gnatovskyi, D.O. Koval, O.V. Senatorova, V.V. and other authors.

At the same time, many issues remain unresolved that need to be comprehensively analyzed and covered. In particular, the issues of clarifying international and national mechanisms of guarantees of protection of victims' rights (prisoners of war, women, children, etc.) in the conditions of armed conflict, of delineation of certain organizational and forensic vectors of protection of the rights of victims in the conditions of the armed conflict in the East of Ukraine, of revision of criminal legal means of protection of persons from commission of war crimes, etc. require additional solutions. It is also indisputable that certain tactical and procedural "tools" of the investigation of war crimes that are committed in the context of an international armed conflict, must be properly disclosed from the standpoint of forensic science and criminal procedure.

\section{Materials and methods}

The methodological basis of the scientific article is formed by general scientific and special methods and techniques of scientific knowledge, that are aimed at an objective and substantiated study of the international legal regime of prisoners of war. The basis of the methodological toolkit is the system analysis, which determined the directions of research of mechanisms of protection of victims' rights in the conditions of armed conflict on the territory of Ukraine. The conceptual apparatus has been enriched with the help of the dialectic method; the essence of such terms as "armed conflict", "war", "international humanitarian law", and the peculiarities of liability for violation of victims' rights in the conditions of armed conflict have been clarified.

Formal and legal method was used for analysis of the legal meaning of international and national legal acts in the field of protection of the rights of children, women, prisoners of war and wounded. The comparative and legal method has allowed to clarify the relationship of universal international treaties with each other, international treaties, and international legal customs regarding the protection of the rights of victims of armed aggression of another country and to study the issue of reflection of international legal requirements in national legislation. The scientific and heuristic potential 
of such philosophical research methods as analysis, synthesis, deduction, induction, abstraction, etc. has been also used.

Thus, the author's methodology of this study is a set of methods and techniques that are based on dialectical analysis of legal documents, empirical data, as well as a critical understanding of the scientific literature on this issue.

\section{Research and results}

General characteristics of the sources of international humanitarian law and national legislation governing legal relations in conditions of the armed aggression.

The basic Law of our state recognizes human life and health as the highest social value (the article 3 of the Constitution of Ukraine) (Constitution of Ukraine, 1996). That is why the state has undertaken to take all measures to protect human rights and fundamental freedoms, guided by the case law of the European Court of Human Rights and other sources of law that take precedence over the norms of national law.

Of course, specific protection mechanisms depend on the nature of the violations. When it comes to human rights violations in the context of the European Convention on Human Rights, it regulates property rights in detail. Not all other international tools allow similarly for the effective protection of this right. Accordingly, in the event of a violation of property rights, an effective mechanism may be for individuals or legal entities to apply to the European Court of Human Rights. If it is a question of violation of the international humanitarian law, then other legal mechanisms will be involved here, the protection of victims will be carried out already within the framework of bringing the perpetrators to justice in national courts. There is also a procedure for resolving the specified disputes in international courts.

Given that the subject of the research is to develop effective mechanisms to protect the rights of victims of the armed conflict in the East of Ukraine and their restoration at the national level given the requirements that have been developed by world practice, it would be logical to clarify the nature of the armed conflict.

Undoubtedly, armed conflict in all its manifestations is a deformation of social relations, which accompanied by sharp contradictions, widespread use of weapons, declining value of human life, rising level of violence and other crime, which is the root cause of committing war crimes. An international armed conflict occurs when an attack on the territory of a state is carried out by another state, or by non-governmental formations 
that are under the control of another state. In this case, it begins to be used after the first shot against the territory of the state or crossing the border by the armed forces of another state. The conflict will also be considered as international if the third country exercises at least general control under non-governmental armed formations. An occupation of the territory of another state is equated to an armed conflict of an international character, even if such an occupation does not meet with armed resistance (Koval and Avramenko, 2019).

It should be noted that the term "armed conflict" is broader in scope than the term "war". This is confirmed by the art. 2 that is general for the Geneva Convention, according to which the norms of these documents are applied not only in the event of a declaration of war, but also in relation to any other armed conflict. According to classical international law, "war" requires availability of several international legal criteria: it must be proclaimed, which usually results in the severance of diplomatic relations and the termination of bilateral international agreements between the belligerents. The fact is that states are at war without declaring war and even they are maintaining diplomatic and contractual relations in recent decades, after the ban on the use of force and the threat of force in the art. 2 of the Charter of the United Nations. No one wants to declare war than to declare to the whole world that you are an aggressor and to bear international legal responsibility for it (Grygoryan, 2009).

Even when a state defends itself against invasion, it often does not even recognize the state of war between it and the aggressor. Undoubtedly, this resulted in the enshrinement of the term "armed conflict" in the Geneva Convention and the gradual departure from the application of the term "war" in the documents of international humanitarian law, leaving it as just ad bellum (Senatorova, 2018).

International humanitarian law is the general name for a set of rules of international law, which are sometimes referred to as the international law of armed conflicts, or the law of war. It regulates the protection of persons who do not participate in or have withdrawn from an armed conflict, as well as regulates the means and methods of armed conflict (Koval and Avramenko, 2019). International humanitarian law or the law of armed conflicts is a branch of international law whose rules and principles limit the application of violence in the time of armed conflicts by making such demands: a) to spare those who do not or have ceased to take a direct part in hostilities; b) to limit violence to the extent that is necessary to achieve the goal of the conflict, which may result (regardless of the causes through which the conflict began) only in weakening the military potential of the opposing side.

The main sources of international humanitarian law, as well as international law in general, are international treaties and international 
customs. Beginning in the third quarter of the nineteenth century, when the process of codification of the laws and customs of war began, the international treaty became the main source of international humanitarian law. Today, international humanitarian law is one of the most conventionally secured branches of international law. In doing so, it is important to note the extremely high level of commitment of states under multilateral agreements. This also applies to the settlement of relations in the field of protection of the rights of victims in the conditions of armed conflict in the East of Ukraine.

Despite the legal uncertainty of the place of international customs in the legal system of Ukraine due to the lack of references to international customs in the art. 9 of the Constitution of Ukraine, there is no doubt that Ukraine is bound by the customary norms of international humanitarian law, which create a system of international legal obligations of Ukraine in the treatment and protection of victims of armed conflicts next to the provisions of the Geneva Convention (Geneva Convention, 1949). This is confirmed by the provisions of the Law of Ukraine "On the bases of domestic and foreign policy", according to which the basis of domestic and foreign policy are based on generally accepted principles and norms of international law (paragraph 1 of the article 2), and foreign policy is based on the following principles: respect for human rights and fundamental freedoms; conscientious fulfillment of the undertaken international obligations; priority of generally recognized norms and principles of international law over norms and principles of national law (paragraph 3 of the article 2).

Undoubtedly, the generally accepted norms and principles of international law include customary norms of international humanitarian law. General provisions regarding the binding nature of obligations under international treaties, approved by the Verkhovna Rada of Ukraine, are contained in the Law of Ukraine "On defense of Ukraine" (parts 2, 5 of the article 2), the Military Doctrine of Ukraine (paragraph 2).

The Constitution of Ukraine in the national legislation provides the basic guarantees of the person on protection, namely: everyone, under all circumstances, has the right to life and inviolability, to personal respect, to respect for his honor, their religious beliefs, the right to the family and other fundamental human rights, the protection of which is enshrined in other regulations, in particular, but not limited to: the Criminal Code of Ukraine, the Code of Civil Protection, the Law of Ukraine "On the armed forces of Ukraine", Law of Ukraine "On ensuring the rights and freedoms of citizens and the legal regime in the temporarily occupied territory of Ukraine", Law of Ukraine "On ensuring the rights and freedoms of internally displaced persons", Therefore, it is incorrect to say that the state of Ukraine is not doing anything for the protection of its citizens at the legislative level in connection with the armed conflict in the East (Executed in Donbass, 2021). 
In our opinion, the main problem is not only the lack of a sufficient number of relevant regulations or the imperfection of their provisions regarding the protection of fundamental rights and freedoms of the population during an armed conflict (although there is enough work in this direction regarding the improvement of the current legislation), but also in the absence of an effective mechanism of their application. We will carry out the scientific analysis of the international and national provisions, which regulate public relations in this sphere, in substantiation of the stated considerations.

International and national mechanisms of guaranteeing the protection of the rights of victims in the conditions of armed conflict.

The protection of civilians, the wounded and the sick, as well as prisoners of war and children, is confirmed by the provisions of the first Additional protocol to the Geneva Conventions. They extend the scope of such protection to any person under the authority of a party, which is involved in the conflict and do not enjoy a more favorable treatment under the Geneva Conventions in the context of an international armed conflict. The commission of a number of acts is prohibited and will remain prohibited at any time and in any place, regardless of whether they are committed by representatives of civil or military bodies (violence against life, health and physical and mental condition of persons; outrage to human dignity; taking hostages; collective punishment; coercion into prostitution or indecent assault in any form (Additional Protocol to the Geneva Convention, 1977). Some of these actions are considered serious violations of international humanitarian law, such as: murder, torture, mutilation, and hostage-taking (serious violations of the Geneva Conventions and the Additional protocol); abuse of human dignity, collective punishment and committing sexual violence, including coercion into prostitution (war crimes in accordance with customary international humanitarian law), for the commission of which the criminal liability must be provided.

As it is noted in the scientific literature with reference to specific facts, most cases of sexual violence, that are related to the armed conflict in eastern Ukraine took place in the context of the deprivation of liberty by illegal armed formations. In such cases, sexual violence was directed against both men and women. Beating and electric shock to the genital area, rape, threats of rape, and forced exposure were used as methods of torture and cruel treatment to punish, humiliate, or confess. Facts of detentions, abductions, rapes, injuries, or killings of victims' relatives, including their children and women, are known. In most cases, sexual violence was also used to force detainees to give up their property or perform other acts that were required by perpetrators as an obvious condition of their safety and release, in areas, which had been controlled by illegal armed formations (CIVIIM, 2019). 
At the national level, the Constitution of Ukraine enshrines the fundamental principles of non-discrimination and humane treatment and provides that everyone has the right to respect for his or her dignity, religious beliefs and practices in all situations (Constitution of Ukraine, 1996). About the establishment of criminal liability for serious violations of international humanitarian law, it should be noted that the content of the provisions of the art. 438 (Violation of laws and customs of war) of the Criminal code of Ukraine is generalized enough, for covering the full range of serious offenses, such as murder, torture, hostage-taking, pimping or Involvement of a person in prostitution, etc.

First, let's turn to the basic guarantees that are provided to women internationally and nationally during an international armed conflict.

Under the first Additional protocol, women are given special protection when their freedom is restricted for reasons that are related to the armed conflict. For example, they are kept in rooms that are separate from those for men (or if women are part of families, such women are kept in the same room with their families), in addition, they are under the direct supervision of women. Cases of pregnant women and mothers of young children on whom such children depend, who are arrested, detained, or interned for reasons that are related to the armed conflict, are considered as a matter of priority (Additional Protocol I to the Geneva Conventions, 1977).

It should be noted that the Criminal Executive Code of Ukraine and the Criminal Procedure Code of Ukraine define specific mechanisms for the protection of women and families in peacetime. However, these provisions were not intended to be applied in time of armed conflict but remain relevant today as they can be applied for the implementation of international humanitarian law and be an informative source of recommendations for an appropriate approach. In particular, the Penal Code provides for the separate detention of women and men during detention (Law of Ukraine, 2003).

In addition, the Criminal Procedure Code of Ukraine stipulates in the art. 535 that imprisonment may be postponed in the case of pregnancy of a convicted person or in the availability of a child under the age of three. Also, this article stipulates not only that during the execution of sentences the court in criminal cases should consider women's cases as a matter of priority (in accordance with the international standard), but also that the judge should consider releasing pregnant women and women with children under the age of three from liability (Law of Ukraine, 2012).

The guide to the application of norms of international humanitarian law in the Armed Forces of Ukraine contains a similar provision that provides for the separation of men and women during captivity (Order of the Minister of Defense of Ukraine, 2004). However, the Guide to the application of norms 
of international humanitarian law in the Armed Forces of Ukraine do not contain provisions regarding most international requirements, namely: families should be kept in family blocks; women should be under the direct supervision of women; the cases of pregnant women and mothers of young children on whom such children depend, who are arrested, detained or interned for reasons that are related to armed conflict, are considered as a matter of priority.

Special additional guarantees are provided to pregnant women and mothers of young children (Denysov and Belousov, 1978). Thus, in the case of an international armed conflict, the cases of pregnant women and mothers of young children on whom such children depend, who are arrested, detained, or interned for reasons that are related to armed conflict, are considered as a matter of priority. The authors of Additional protocol I sought to provide a legal basis for the early opportunity of release of pregnant women and mothers with young children by this provision. However, the authors of the Additional protocol failed to impose an absolute ban on the death penalty for pregnant women and mothers of young children in cases of international armed conflict. Such a ban contradicted some provisions of the national legislations of a number of countries (Yatsetiuk, 2007). However, international humanitarian law recommends that such sentences be avoided as far as possible for both women, who are prisoners of war and civilian women.

International humanitarian law places considerable emphasis in its provisions on providing the protection of women, in particular protection against rape, coercion into prostitution or any other form of encroachment on their morality (Geneva Convention, 1949). Thus, committing sexual violence, in particular rape (the article 152 of the Criminal Code of Ukraine) and pimping or involving a person in prostitution (the article 303 of the Criminal Code of Ukraine), constitutes a serious violation of the international humanitarian law in accordance with its customary norms (Order of the Minister of Defense of Ukraine, 2004).

At the same time, in our opinion, the level of detail of the art. 438 of the Criminal Code of Ukraine is insufficient. There is a high probability that in such an edition, it does not provide the accuracy and specificity that underlies effective bring to justice for appropriate forms of prohibited conduct.

It should be emphasized that the Guide to the application of norms of international humanitarian law in the Armed Forces of Ukraine do not provide that rape, coercion into prostitution or any other form of encroachment on a person's morality constitutes a serious violation of international humanitarian law (Order of the Minister of Defense of Ukraine, 2004). Such actions must be described as serious violations of international humanitarian law for ensuring the effectiveness of bringing the perpetrators 
to justice under the art. 438 of the Criminal code of Ukraine, such actions should be characterized as serious violations of international humanitarian law, and the art. 438 of the Criminal Code should be interpreted in view of their new qualification.

The first and second Geneva Conventions require governments of the countries to protect and respect members of personnel of the armed forces who are wounded or ill during the armed conflict (Verkhovna Rada of Ukraine, 1949). It should be noted that the art. 12 of the specified conventions are applied both to sick and wounded persons of the Ukrainian military, and to the wounded, sick and shipwrecked people, who are part of the enemy forces (for example, prisoners of war). It undertakes to ensure humane treatment and care without any discrimination on grounds of sex, race, nationality, religion, political opinion, or other similar criteria (Verkhovna Rada of Ukraine, 1949). Ukraine is obliged to prohibit any attempt on the life of the sick and wounded persons, or any violence against them, i.e., to kill, destroy, torture, or conduct biological experiments. It is forbidden to intentionally leave such persons without medical care and services, to intentionally create conditions for their infection (Verkhovna Rada of Ukraine, 1949).

We believe that it is necessary to apply the provisions of namely criminal law for the commission of the specified acts that are committed against sick and injured persons, as these acts are tantamount to serious violations of international humanitarian law (e.g., murder, torture, and biological experiments).

It must be noted that the fundamental principles of non-discrimination and humane treatment are enshrined in the Constitution of Ukraine, and therefore are applied at any time, including to the wounded and the sick persons from among the personnel of the armed forces.

With regard to acts that equate to serious violations of international humanitarian law, the art. 434 of the Criminal code of Ukraine unambiguously establishes criminal liability for cruel treatment of wounded and sick prisoners of war as for a war crime, as well as for negligent performance of duties to the wounded and sick persons by those, who are obligated to provide them with medical assistance and care. The procedure of prosecuting for committing such acts often depends on law enforcement practice.

In conditions of armed conflict, one of the common categories of victims of war is prisoners of war. The Third Geneva Convention stipulates that prisoner of war always have the right to humane treatment. International humanitarian law prohibits subjecting them to physical injury or any medical/scientific experiments, which are not justified by the need of committing medical, dental, or inpatient treatment of a prisoner of war, 
as well as requires establishing responsibility for committing such acts (Additional Protocol I to the Geneva Conventions, 1977).

States have obligations to stop other violations of international humanitarian law, which do not amount to serious violations, but require, at a minimum, the adoption of disciplinary sanctions. In particular, protection of prisoners of war should be provided in situations where they are particularly vulnerable, such as intimidation, insults, and when they are the object of "public interest". The application of repression by the state, which keeps in captivity, is also not considered a serious violation and should be subject to disciplinary sanctions. In addition, the Government of Ukraine should provide special protection to women prisoners of war (for example, early repatriation for the pregnant women with all due respect, which corresponds to their gender, and in all cases, they must be treated as favorably as the men (ICRC, 1958; Geneva Convention, 1949)).

International humanitarian law legally enshrines the basic principle of equality between men and women, developing it in paragraphs that prohibit discrimination. Namely, the art. 16 III of the Geneva Convention and the art. 75 of Additional protocol I, as well as the art. 4 of Additional protocol II provide the treatment without any adverse difference that is based on the signs of gender (Geneva Convention, 1949; Additional Protocol to the Geneva Convention, 1977). It is also noted that women should be treated in all cases no worse than men. This means that women use all the rights and freedoms that are provided by the Convention on the treatment of prisoners of war. Accordingly, any discriminatory measures resulting from the application of the Convention are prohibited. That is, women, who are prisoners of war have the right to protection of rights and freedoms, as well as men, who are prisoners of war.

The article 434 of the Criminal Code of Ukraine directly defines the cruel treatment of prisoners of war as a war crime. However, such actions may not predict the application of appropriate sanctions (the punishment of up to three years imprisonment). Alternatively, the art. 438 of the Criminal code of Ukraine (which is applied to civilians and to servicemen) can also be applied, because it establishes that the cruel treatment of prisoners of war, contrary to the provisions of the conventions, is punishable by eight to twelve years imprisonment. because it establishes that the cruel treatment of prisoners of war, contrary to the provisions of the conventions, is punishable by eight to twelve years imprisonment. Depending on how this provision is applied in practice and the actual circumstances of the alleged violations, this may or may not be sufficient to effectively stop these violations by bringing the perpetrators to justice.

At the same time, it should be noted that in addition to these provisions, Ukrainian legal means do not reflect many requirements of international humanitarian law, including: procedures regarding detention in awaiting 
trial; rights of the defense, such as the right to call witnesses and have an interpreter; the preconditions for the execution of the sentence and the necessary guarantees, such as the impossibility of depriving the privileges that are enshrined in his rank, or the right to do physical exercises and be in the fresh air during at least two hours.

At the same time, the Constitution of Ukraine contains the basic judicial guarantees, which are applied to prisoners of war (for example, the right to be immediately informed about the reasons why measures have been taken, the presumption of innocence, the right to consultation) (Constitution of Ukraine, 1996). The specific requirements that are related to the status of prisoners of war are not regulated at the constitutional level.

The Criminal Code of Ukraine provides for criminal liability of a prisoner of war in three cases in the part of determining the penalties for committing crimes: voluntary participation of a prisoner of war in any work of military significance or other measures that may knowingly cause harm to Ukraine or allied states, in the absence of signs of treason; violence against or illtreatment of other prisoners of war by another prisoner of war, who is in the position of a senior; the commission by a serviceman, who is in captivity of actions that are aimed at harming other prisoners of war, for selfish motives or in order to ensure a lenient attitude on the part of the enemy (Law of Ukraine, 2001).

Although the basic judicial guarantees are provided by the Constitution of Ukraine, the Criminal Code and the Code of Criminal Procedure, these legal acts do not take into account the special requirements that are related to the status of prisoners of war. Other measures of implementation are inadequately defined, making it impossible to ensure a comprehensive implementation regime for the use of criminal penalties for prisoners of war (for example, notification of the case, the rights of the person and means of its protection, the conditions of action of the sentence, the right to appeal, execution of punishment, etc.).

It is advisable to provide a brief overview of the basic safeguards regarding children during an armed conflict of international nature. Thus, the main international legal instrument, which defines the rights of children, is the Convention on the rights of the child, which defines that all states-parties are obliged to take all possible measures to ensure the protection and care of children, who are affected by the armed conflict (Verkhovna Rada of Ukraine, 1989).

The issue of protection of children in the time of the armed conflict is governed by the Geneva Convention about the protection of civilian persons in the time of war and the Additional protocols I and II. In particular, the Convention emphasizes that children have the right, under all circumstances, to personal respect, respect for their honor, the right to a family, their 
religious beliefs and rites, habits, and customs. They should always be treated humanely and protected, from any act of violence or intimidation, from the insults and curiosity of the crowd (Geneva Convention, 1949).

A child, who has suffered because of hostilities and armed conflicts, is a category that is defined in the Law of Ukraine "On child protection" (Verkhovna Rada of Ukraine, 2001). The law provides for the possibility of obtaining the status of a child, who has suffered because of hostilities and armed conflicts (Cabinet of Ministers, 2017). The right to receive this status have children and persons who at the time of the war were not 18 years of age (adult) and who as a result of hostilities and armed conflicts: received injuries, contusions, mutilation; experienced physical and sexual violence; were abducted or illegally taken out from Ukraine; were involved to the participation in actions of paramilitary or armed formations; were illegally detained, including in captivity; suffered psychological violence.

If we talk about criminal legal mechanisms of protection of children, who are victims of crimes, that had been committed in the conditions of an armed conflict, we believe that the article 438 of the Criminal Code of Ukraine is sufficiently voluminous for ensuring the prosecution of persons, who are responsible for conscription and the use of children during the armed conflicts as violators of laws and customs of war (Law of Ukraine, 2001). Such approach to criminalization is general and does not detail this process, which is the basis for effective prosecution for the committing of crimes that were committed in the armed conflict.

There are several regulations (Law of Ukraine "On child protection" and the Law of Ukraine "On military duty and military service") in Ukraine, aimed at regulating issues regarding the use of children during the armed conflicts. Their provisions seem to additional detail the art. 438 of the Criminal Code of Ukraine. However, when viewed in general terms, Ukrainian legal means do not contain sufficiently detailed provisions regarding the prohibited acts and the nature of criminal punishment. Although, certain provisions indicate that the use of child-soldiers and their compulsory conscription are prohibited, the provisions do not explain the essence of a serious violation of the international humanitarian law, which becomes the result of conscription of children for military service and their use (without coercion or obligation), for the commission of which it is necessary to apply the criminal punishment.

As for the special protection of children during an armed conflict, the Law of Ukraine "On child protection" provides general protection of the child during an armed conflict. The amendments enshrine specific measures of protection of children, who are affected by hostilities or armed conflict, such as specific obligations of social services (Verkhovna Rada of Ukraine, 2001). 
In this segment of activity, Ukraine is taking all necessary and possible measures for searching and returning children to Ukraine, who have been illegally taken abroad, including in connection with circumstances that are related to hostilities and armed conflicts (Verkhovna Rada of Ukraine, 2001). In particular, the protection of children who are in the zone of hostilities and armed conflicts, and children who have suffered as a result of hostilities and armed conflicts.

At the same time, it is necessary to emphasize that the legal means of Ukraine do not take into account the following: if, in exceptional cases, children under the age of 15 are directly involved in hostilities and are taken prisoner by the enemy, they continue using special protection due to the status of the child, regardless of whether they are prisoners of war; in the case of arrest, detention or internment for reasons of armed conflict, children must be kept in rooms that are separate from those for adults.

It should be noted that the above-mentioned obligations arising from the Convention on the rights of the child, the Optional Protocol thereto, as well as customary international law, are also applied during non-international armed conflict. In particular, the hiring or recruitment of children under the age of 15 into the armed forces, or their use for active participation in hostilities, are also considered as a serious violation of international humanitarian law during a non-international armed conflict in accordance with customary international humanitarian law and the article 8 of the Rome Statute of the International criminal court (Rome Statute, 2002).

Progressive ones, given the prospects of the specified by us problem regarding developing legal mechanisms of restoring the rights of victims, which are violated as a result of armed aggression in the East of Ukraine, are the provisions of the draft Law of Ukraine "On protection of property rights and other real rights of persons, who are affected by the armed aggression", that was registered under № 5177 from 01.03.2021, the purpose of which is the protection of property rights of persons that are violated as a result of armed aggression through the introduction of mechanisms of restitution, as well as the compensation for property damage that has been caused to victims of the armed aggression in accordance with international and European human rights standards, in particular the practice of the European Court of Human Rights.

One of the main advantages of the specified bill is that in the case of its adoption of the condition of receipt, the grounds for refusal in providing, the amount of compensation, etc. will be introduced by law, the rules of which will have a higher legal force compared to the resolutions of the Cabinet of Ministers of Ukraine. At the same time, the development of relevant implementing regulations for fulfilment of the provisions of the law will allow to create a full-fledged, comprehensive compensatory mechanism. In addition to the above, the availability of a legislative mechanism 
will contribute to the proper implementation of the international legal obligations of Ukraine that have been undertaken in accordance with international treaties (Law of Ukraine, 2021).

Regarding the compliance of the doctrine of criminal law with the requirements of international humanitarian law in terms of criminalization of crimes that were committed in conditions of the armed conflict.

The issue of criminalization of certain illegal acts, which are recognized by the international community as war crimes but classified as "ordinary" criminal offenses at the national level, needs increased attention.

Objective principles of determining the grounds for the application (criminalization) or refusing the application (decriminalization) of criminal legal influence should be recognized as a constant problem of criminal law (Kozachenko et al., 2021). We have to state that the perpetrators of most war crimes today, unfortunately, manage to avoid criminal prosecution. Accordingly, the possibility of compensation by such persons for the damage that has been caused to the victims is minimized. It is well known that the war crimes, by their nature, are one of the heaviest and most serious crimes that have been known to humanity. Under international law, the state on whose territory war crimes is committed must actively investigate and bring the perpetrators to justice (Nazarchuk, 2020).

However, Ukraine is not always able to adequately respond to hostilities in the temporarily occupied and adjacent territories at present. For example, there are no defined in detail norms that determine the illegality of certain actions in an armed conflict in the Criminal Code of Ukraine, in addition to the art. 438. Also, there is no clarification of what war crimes are, which among them are light, medium, heavy, which is a gradation of degrees of responsibility. The specified problem needs a comprehensive solution. Some lawyers rightly consider the adoption of the law on transitional justice to be a way out of this situation (Bida, 2021).

The realities of today in the East of Ukraine indicate the imperfection of certain norms of the Criminal Code of Ukraine, in particular, the lack of legal norms in it that would correspond to socially dangerous acts, which have been committed in the zone of holding the Joint Forces Operation in the conditions of the armed conflict. Currently, there is an urgent need to revise of sections XIX-XX of the Criminal Code in order to include in their norms, which would provide for the criminal liability for all actions against the interests of the people of Ukraine.

In our opinion, for the effective work of the institutions of executive power in Ukraine in the direction of protection of the rights of victims in the conditions of the armed conflict in the East of Ukraine there are not enough legislative instruments, which would promote more constructive work and increase responsibility and accountability regarding the actions and 
measures that have been committed, which would be both: the expected signals for citizens of the country who are under occupation or have been forced to leave the occupied territory; the signals for collaborationists and violators of the regime of sanctions about the inevitability of liability for the actions that have been committed; the leadership of other countries and international organizations, as a confirmation of the sequence of actions of the authorities of Ukraine, in its pursuit to deoccupation and reintegration of temporarily lost territories.

I. Nazarchuk rightly recognizes the imperfection of the legislation and its inconsistency with international norms as one of the reasons. Current art. 438 of the Criminal code of Ukraine ("Violation of laws and customs of war") is enough generalized, therefore, there is an obvious need to specify the elements of war offences in national law, defining all serious violations of International humanitarian law as war crimes. Thus, there is an obvious need to specify the elements of the war offences in the national legislation (Nazarchuk I. Military) (Nazarchuk, 2020).

Undoubtedly, we believe that it is necessary to be guided by practice of the international criminal courts, the doctrine, authoritative comments of the international economic law and provisions of the international agreements in the application of art. 438 of the Criminal code of Ukraine. In doing so, the list of actions that may be considered as violations of the laws and customs of war, is not necessarily to be coincided with the list from the art. 8 of the Rome Statute, or with a list of serious violations of international economic law. It can be expanded, but not arbitrarily. In any case, the expansion of the list of the specified actions should find support in the international practice. Otherwise, Ukraine will almost certainly face cases against itself in the European Court of Human Rights.

Considering this, we suggest focusing on the list of acts that can be classified as violations of the laws and customs of war that has been suggested in the draft law "On amendments to certain legislative acts of Ukraine to ensure harmonization of criminal legislation with the provisions of international law” № 9438.

This is, in particular, the art. 437 "Aggression", the art. 437 "Crimes against humanity", the art. 438 "War crimes against persons", the art. 438 "War crimes against justice", the art. 438 "War crimes against property", the art. 438 "War crimes against humanitarian operations and the use of symbols", the art. 438 "War crimes, which consist in the application of prohibited methods of warfare", the art. 438 "War crimes, which consist in the application of prohibited means of warfare", the art. 438 "War crimes against the movable and immovable property, buildings and centers that are protected under international humanitarian law", the art. 436 "Peculiarities of criminal liability for crimes against the foundations of international law", the section XXI "Crimes against the international 
law and order"(Vakhrushev, 1999; Grushko, 2010; Grygoryan, 2009; Constitution of Ukraine, 1996; Koval and Avramenko, 2019; Gnatovskyi, 2017).

The specified list of actions is at least conceptuallyin linewith international standards and obligations of Ukraine under international treaties regarding criminalization of violations of international humanitarian law. In our opinion, the introduction of appropriate amendments to the Criminal Code will undoubtedly assist the victims of armed aggression in the East of Ukraine in gaining the status of a victim in criminal proceedings, and, consequently, will make it possible to use the determined by the criminal procedure law mechanism of compensation for damage that has been caused by a criminal offense.

Features of detection and collection of evidence during the investigation of crimes that were committed during the armed conflict in the East of Ukraine.

Given the problem that is outlined in the introductory part of the article, we consider it appropriate to identify other directions of protection of the rights of victims in the conditions of the armed conflict in the East of Ukraine. In particular, the research of the peculiarities of detecting and gathering evidence during the investigation of the identified crimes deserves attention. After all, in our opinion, as opposed to the criminal process as it is commonly understood, realization of the procedure of investigation in cases of war crimes, namely, such crimes that were committed in the conditions of the armed conflict in the East of Ukraine, need to be revised and improved.

The complexity and diversity of the problem of determining the procedural order of investigation of war crimes is due to the following features: a high degree of interference in the internal affairs of the state, which significantly affects the national interests of the other side of the armed conflict; the prosecution of persons who have committed war crimes in the territory of another country party to the armed conflict and fall under its jurisdiction in particular; one of the parties in whose territory the crime was committed, for some reason, does not provide an objective and qualified investigation, and in the list of cases opposes the investigation; limited opportunities to gather evidences in the opponent's country, when there are some witnesses, suspects, etc.; lack of legal regulation of the grounds and procedure for conducting investigative and other procedural actions on the territory of the other party of the conflict; the inevitable conflict of constitutional, procedural and substantive norms that act in the territory of the parties to the conflict; non-fulfillment of requests for the international legal assistance by the parties, etc. 
A principled feature of the procedural order of investigation of war crimes is that the perpetrators belong to the parties to the conflict, and for the establishment of the involvement of specific service members (pilots, artillerymen, snipers, etc.) of the other party, who gave and carried out orders about air strikes, shelling and destruction of civilians, other war crimes, proof of their guilt, etc., it is necessary to conduct investigative (in particular, such specific ones as interrogation of prisoners of war, research of places of mass burials, analysis of radio talks, etc.) and procedural actions on the territory and with the participation of the party of conflict. We believe that national investigative bodies, guided solely by the provisions of the Criminal Procedure Code of Ukraine without regard to international legal norms and mechanisms of investigating such crimes, without holding investigative and procedural actions on the territory and with the participation of the other party to the armed conflict or the absence of a truce, will not be able to effectively use the potential of criminal procedure means and to ensure the investigation and opportunity of prosecution of representatives of the other party to the conflict, who are responsible for war crimes, except, of course, of military-violent scenarios of purely hypothetical nature.

At the same time, national law enforcement agencies face the problem of limiting their powers under the national Code of Criminal Procedure after initiating criminal cases of the specified category on the principle of extraterritorial criminal jurisdiction, at the stage of investigation and presentation of the evidence to the representatives of the other party of conflict. At the same time, namely the fact of initiating a criminal case regarding representatives of the other side of the conflict has not yet indicated that any of them will be prosecuted. The specified problem is beyond the scope of the opportunities of national criminal procedure legislation or giving the legal force within the legal system of Ukraine to the international treaties.

Thus, it can be argued that there are specific patterns of detection, documentation and investigation of crimes that were committed in the conditions of the armed conflict. Knowledge of such features, prompt, skillful and coordinated cooperation in the specified area is extremely important from the standpoint of ensuring the rights and legal interests of victims, both military and civilian.

One of the significant steps that are aimed at improving the effectiveness of investigations of the war crimes, including those committed in the conditions of an international armed conflict, is a signing on October 21, 2019 of the order on creation in the Prosecutor General's Office of Ukraine of the Department of supervision in criminal proceedings concerning crimes, that are committed in an armed conflict, whose activity will focus on overseeing the investigation of crimes that are committed in the temporarily 
occupied territory of the Autonomous Republic of Crimea and the city of Sevastopol, in the temporarily occupied districts of Donetsk and Luhansk regions and in the conditions of armed conflict (Ministry for Reintegration of the Temporary Occupied Territories, 2021). All this creates a vertical for coordinating the efforts of all law enforcement agencies in the investigation of war crimes and crimes against humanity, will promote the systematic fixation and systematization of evidence of guilt of specific persons in committing illegal acts, in search for logical connection between the harm that has been caused to a person and the relevant criminal acts and, as a result, to create appropriate conditions for the restoration of the rights of victims of the armed conflict in the East of Ukraine.

\section{Conclusions}

Based on the results of the problems that are covered in the scientific article, we can make certain conclusions, which are aimed at determining the prospects of the protection of the rights of victims in the conditions of the armed conflict in eastern Ukraine, given the requirements of the international community.

1. Full fulfillment by Ukraine of its obligations in the fight against impunity for the heaviest crimes against international law, that have been committed in the conditions of an armed conflict, should be ensured by applying the Criminal Code of Ukraine (including the Section XX of the Special Part, but also a list of provisions of the General Part) in accordance with the current state of development of international criminal law. In particular, we see the need to expand and specify the compositions of war crimes in the national law. After all, in accordance with only the provisions of the national Criminal and Criminal Procedure Code, without regard to international legal norms and mechanisms for the investigation of war crimes, without conducting investigative and procedural actions on the territory and with the participation of the other party to the armed conflict or the absence of a truce, investigative bodies will not be able to effectively use the potential of criminal procedural means in achieving the goals of criminal proceedings, to ensure the restoration of the rights of victims of the armed conflict and compensation for the damage that has been caused to them.

2. Arguments in favor of creating a legislative mechanism of compensation to victims of the armed aggression in the south and east of Ukraine are provided, which would cover various issues of protection of property rights of persons that have been violated by the armed conflict, by introducing mechanisms of restitution, as well as 
compensation for property damage, in accordance with international and European standards of human rights, in particular the practice of the European Court of Human Rights.

3. The expediency in: a) introduction of the National center of information and documentation on victims of the armed aggression (dead, wounded, persons that lost property, prisoners of war, children, etc.), which will unite all existing state registers with the provision of access to the relevant state bodies and local governments; b) the creation of the State Register of property that has been destroyed, damaged and lost as a result of the armed aggression, as a single state information and telecommunication system, that is intended for the accumulation of information about property, which has been destroyed, damaged or lost as a result of the armed aggression, registration of persons, who have a right to compensation for such property or the restitution, as well as the accrued amounts of compensation, the committed restitutions, etc. The specified data can be used for forming a consolidated claim of Ukraine to the aggressor state regarding the implementation of its international legal responsibility for the armed aggression against Ukraine.

Finally, it should be noted that the requirements for the scope of the article did not allow outlining all aspects of such a multifaceted problem, as a protection of the rights of the victim in the conditions of the armed aggression in the East of Ukraine, and encouraged to the separation of only individual problems and the development on the basis of their scientific analysis of the relevant recommendations of an organizational and legal nature, which are governed by national law and are complied with the provisions of international humanitarian law.

\section{Bibliographic References}

ADDITIONAL PROTOCOL I TO THE GENEVA CONVENTION. 1977. Additional Protocol I to the Geneva Convention of 12 August 1949 on the Protection of Victims of International Armed Conflicts (Protocol I) of 8 June 1977. Available online. In: http://www.icrc.org/IHL. nsf/\%28SPF\%29/party_main_treaties/\$File/HL_and_other_related_ Treaties.pd. Date of consultation: 17/08/2020.

ADDITIONAL PROTOCOLTOTHE GENEVACONVENTION.1977.Additional Protocol to the Geneva Convention of 12 August 1949, regarding the protection of victims of non-international armed conflicts of 8 June 1977. Available online. In: http: // zakono. work. gov.ua/laws/show/995_200. Date of consultation: 18/08/2020. 
Olha Sosnina, Oleksandr Mykytiv, Halyna Mykytiv, Tetiana Kolenichenko y Andrii Holovach

BIDA, Oleksiy. 2021. "Documenting war crimes is a natural process of restoring justice". Available online. In: https://helsinki.org.ua/articles/oleksiybida-dokumentuvannia-voiennykh-zlochyniv-pryrodniy-protsesvidnovlennia-spravedlyvosti. Date of consultation: 15/03/2021.

CABINET OF MINISTERS. 2017. Procedure for granting the status of a child that was affected by hostilities and armed conflicts: Resolution of the Cabinet of Ministers of Ukraine of 05.04.2017 № 268 (as amended). Available online. In: https://zakon.rada.gov.ua/laws/show/268 -2017\% Do\% BF. Date of consultation: 18/08/2020.

CIVIIM. 2019. "Victims of the armed conflict in eastern Ukraine in 20142018" Available online. In: https://civilmplus.org/wp-content/ uploads/2019/o1/Web_Victim_A5_ukr.pdf. Date of consultation: $18 / 08 / 2020$.

CONSTITUTION OF UKRAINE. 1996. Law of Ukraine of June 28, 1996, № 254k / 96-vr. Available online. In: http://zakon3.rada.gov.ua/laws/ show/254к/96-вр. Date of consultation: 18/08/2020.

DENYSOV, Viktor; BELOUSOV, Mykhailo. 1978. "An important stage in the development of international humanitarian law" In Soviet law. Vol. 3, No. 7. pp. 99-114.

DRAFT LAW. 2018. On amendments to certain legislative acts of Ukraine concerning ensuring harmonization of criminallegislation with provisions of international law of December 20, 2018. № 9438. Available online. In: http://w1.c1.rada.gov.ua/pls/zweb2/webproc4_1?pf3511=65266. Date of consultation: 19/08/2020.

DRAFT LAW. 2021. On protection of property rights and other real rights of persons, who are victims of the armed aggression of March 1, 2021. № 5177 Available online. In: https://w1.c1.rada.gov.ua/pls/zweb2/ webproc4_1?pf3511=71272. Date of consultation: 19/08/2020.

EXECUTED IN DONBASS. 2021. "Executed in Donbass: facts of torture and murder in eastern Ukraine" Available online. In: http://book.mb.net.ua/ visnovki-ta-rekomindaci\%D1\%97/. Date of consultation: 19/03/2021.

GENEVA CONVENTION. 1864. Geneva Convention for the amelioration of the condition of the wounded and sick soldiers in Ground War, 22.08.1864. Date of consultation: 18/08/2020.

GENEVA CONVENTION. 1949. 14. Geneva Convention for the amelioration of the condition of the wounded, sick and shipwrecked in the armed forces at sea of 12 August 1949. Available online. In: http://zakono.rada.gov. ua/ laws / show / 995_152. Date of consultation: 18/08/2020. 
GENEVA CONVENTION. 1949. Geneva Convention on the protection of civilian persons in time of war of 12 August 1949. Available online. In: http://zakon4.rada.gov.ua/laws/show/995_154. Date of consultation: 17/08/2020.

GENEVA CONVENTION. 1949. Geneva Convention on the treatment of prisoners of war of August 12, 1949. Available online. In: http://zakon5. rada.gov.ua/ laws / show / 995_153. Date of consultation: 18/08/2020.

GNATOVSKYI, Mykola. 2017. Respect for human rights in the context of armed conflict in Ukraine: the application by courts of international humanitarian law and human rights standards. Available online. In: https://newjustice.org.ua/wp-content/uploads/2017/o9/Report_ Respect-for-HR-in-Conflict_Gnatovsky_UKR.pdf. Date of consultation: 15/08/2020.

GRUSHKO, Malvina. 2010. "Protection of the rights of women prisoners of war in armed conflict" In Journal of Kyiv University of Law. Vol. 3, pp. 295311.

GRYGORYAN, Grygoriy. 2009. Investigation of crimes that are committed by servicemen of the armed forces of the republic of Armenia in areas of armed conflict. AutoAbstract of dissertation of candidate of legal sciences: 12.00.09. p. 211.

GRYGORYAN, Grygoriy. 2018. International legal basis for the investigation of war crimes. On the materials of the Nagorno-Karabakh armed conflict. Monograph. Yerevan, Ukraine.

ICRC. 1958. Commentary of Article 14 of Geneva Convention III. Date of consultation: 19/08/2020.

KOVAL, Dmytro; AVRAMENKO, Roman. 2019. Features of the investigation of international crimes that have been committed in the conditions of the armed conflict in Donbas. War crimes. Kyiv, Ukraine.

KOZACHENKO, Oleksandr; SOTULA, Oleksandr; BIBLENKO, Vasyl; GIULYAKOV, Kostiantyn; BEREZNIAKOV, Oleksandr. 2021. "The substrate of criminal-legal influence” In: CUESTIONES POLÍTICAS. Vol. 39, No.68. pp. 443-464.

LAW OF UKRAINE. 2001. Criminal Code of Ukraine: Law of Ukraine of April 5, 2001, № 2341-III. Available online. In: http://zakon5.rada.gov.ua/ laws/show/2341-14/print1469257658644343. Date of consultation: 18/08/2020. 
Olha Sosnina, Oleksandr Mykytiv, Halyna Mykytiv, Tetiana Kolenichenko y Andrii Holovach International Aspects of the Protection of Victims' Rights in the Conditions of Armed Conflict in Ukraine

LAW OF UKRAINE. 2003. Criminal Enforcement Code of Ukraine: Law of Ukraine of July 11, 2003, № 1129-IV. Available online. In: https://zakon. rada.gov.ua/laws/show/1129-15. Date of consultation: 18/08/2020.

LAW OF UKRAINE. 2012. Criminal Procedure Code of Ukraine: Law of Ukraine of April 13, 2012, № 4651-VI. Available online. In: https://zakon.rada. gov.ua/laws/show/4651-17. Date of consultation: 18/08/2020.

LAW OF UKRAINE. 2021. Explanatory note to the Law on protection of property rights and other real rights of persons, who are victims of armed aggression dated 01.03.2021 № 5177. Available online. In: https:// w1.c1.rada.gov.ua/pls/zweb2/webproc4_1?pf3511= 71272. Date of consultation: 18/03/2021.

MINISTRY FOR REINTEGRATION OF THE TEMPORARY OCCUPIED TERRITORIES. 2021. A department for war crimes has been established in the the Procurator-General's Office of Ukraine. Available online. In: https://mtot.gov.ua/v-gpu-stvoreno-departament-z-viskovih-zlochiniv. Date of consultation: 15/03/2021.

NAZARCHUK, Iryna. 2020. War crimes in the Donbass. What are the difficulties of investigating and bringing the perpetrators to justice? Available online. In: https://www.radiosvoboda.org/a/war-crimedonbas-problems/30733783.html. Date of consultation: 18/08/2020.

ORDER OF THE MINISTER OF DEFENSE OF UKRAINE. 2004. Guide to the Application of International Humanitarian Law in the Armed Forces of Ukraine: Order of the Minister of Defense of Ukraine of September 11, 2004, № 400. p. 144. Kyiv, Ukraine.

ROME STATUTE. 2002. Rome Statute of the International Criminal Court of 16.01.2002. Available online. In: https://zakon.rada.gov.ua/laws/ show/995_588. Date of consultation: 19/08/2020.

SENATOROVA, Oksana. 2018. Human rights and armed conflicts. textbook. p.208. Kyiv, Ukraine.

VAKHRUSHEV, Valentin. 1999. "Local wars and armed conflicts: nature and influence on the art of war" In: Military thought. Vol. 4, pp. 24-36.

VERKHOVNA RADA OF UKRAINE. 1949. Convention on the Improvement of the Fate of the Wounded and Sick in Armed Forces of August 12, 1949. Available online. In: http://zakon4.rada.gov.ua/laws/show/995_1. Date of consultation: 18/08/2020.

VERKHOVNA RADA OF UKRAINE. 1989. Convention on the Rights of the Child of November 20, 1989. Available online. In: https://zakon.rada. gov.ua/laws/show/995_021. Date of consultation: 18/08/2020. 
VERKHOVNA RADA OF UKRAINE. 2001. On Child Protection: Law of Ukraine of April 26, 2001. № 2402-III. Available online. In: https://zakon.rada. gov.ua/laws/show/2402-14. Date of consultation: 18/08/2020.

YATSETIUK, Oleksandr. 2007. "Protection of women and children in international humanitarian law" In: International public and private law. Vol. 5, pp. 16-22. 
Vol. 39 N $^{\circ} 71$

Esta revista fue editada en formato digital y publicada en diciembre de 2021, por el Fondo Editorial Serbiluz, Universidad del Zulia. Maracaibo-Venezuela 